\title{
Kinerja kelembagaan program sanitasi lingkungan berbasis masyarakat (SLBM)
}

\section{Institutional performance of community-based environmental sanitation program (SLBM)}

\author{
Denok Kurniasih, Paulus Israwan Setyoko, M. Imron \\ Jurusan Ilmu Administrasi Negara, FISIP, Universitas Jenderal Soedirman (UNSOED), Purwokerto, \\ Jawa Tengah, Indonesia \\ Jalan HR. Bunyamin No 993 Purwokerto 53122 \\ Jawa Tengah, Indonesia \\ E-mail: denokkurniasih@yahoo.com
}

\begin{abstract}
SLBM Program implementation in Banyumas Regency involves many stakeholders, one of them is community. Through KSM, community has authority to manage program from, beside government roles as facilitator. Thus, institutional system is required to support performance of KSM. By using descriptive qualitative approach, this research aimed to analyze institutional performances of KSM and aspects which is able to support and inhibit the institutional performance of KSM. This research found that institutional performance of KSM has not been able to reach policy goals. This can be seen from community participation in SLBM program. Program's effectiveness is also not optimal. Thus, there have been no changes in the community habits of sanitation-related issues. Moreover, some of support and inhibit aspects of institutional performance of KSM has indentified.
\end{abstract}

Keywords: community-based program, institutional performances, self-help groups

\begin{abstract}
Abstrak
Implementasi program Sanitasi Lingkungan Berbasis Masyarakat (SLBM) di Kabupaten Banyumas melibatkan berbagai stakeholders, salah satunya masyarakat. Melalui kelompok swadaya masyarakat (KSM), masyarakat diberikan kewenangan untuk mengelola program sejak awal, sementara pemerintah hanya berperan sebagai fasilitator. Dengan ini, dibutuhkan sistem kelembagaan guna mendukung kinerja KSM. Melalui pendekatan deskriptif kualitatif, penelitian ini bermaksud menganalisa kinerja kelembagaan KSM serta aspek yang mampu mendukung dan menghambat kinerja kelembagaan KSM. Temuan penelitian ini mengungkapkan bahwa kinerja kelembagaan KSM belum mampu mencapai tujuan kebijakan. Indikasinya, partisipasi masyarakat dalam program SLBM tercatat masih minim secara kuantitas. Akibatnya efektivitas program juga cenderung belum optimal. Dengan demikian, belum ditemukan adanya perubahan kebiasaan masyarakat terkait persoalan sanitasi. Tak hanya itu, beberapa aspek penghambat dan pendukung kinerja kelembagaan KSM juga teridentifikasi.
\end{abstract}

Kata Kunci: kinerja kelembagaan, kelompok swadaya masyarakat, program berbasis masyarakat

\section{Pendahuluan}

Tulisan ini memberi kontribusi bagi teori dan praktek kelembagaan (institutional theory and practices). Perspektif kelembagaan digunakan dalam analisis ini karena kelembagaan memegang peranan penting dalam keberhasilan implementasi suatu program. Studi yang mengadopsi perspektif kelembagaan dalam menganalisis kinerja suatu kebijakan atau program telah tumbuh dan berkembang selama dekade terakhir ini, misalnya penelitian yang dilakukan oleh Modell (2009), Adolfsson \& Wikstro M (2007) dan Polk (2011). Kelembagaan, baik dalam proses pembuatan kebijakan, perencanaan maupun implementasi kebijakan lebih banyak dikaitkan dengan upaya memecahkan masalah sosial dan lingkungan (Baker \& Rennie 2012). Penelitian sebelumnya menjelaskan bahwa kelembagaan diperlukan untuk memfasilitasi pemerintah dan lintas sektor lainnya untuk menciptakan keberlangsungan jangka panjang suatu sistem sosial (Cash et al. 2006, Brondizio et al. 2009, Ta'bara \& Pahl-Wostl 2007). 
Analisis kelembagaan dalam konteks implementasi program memberikan arahan dalam melihat proses interaksi yang dibangun para pelaksana program dan bagaimana organisasi dirancang untuk mengadopsi kebijakan serta bagaimana menghadapi lingkungan dan budaya (Burch 2007, Alexander 2005). Sementara itu teori institusional dalam pendekatan sosiologi lebih berkaitan dengan peran dan norma-norma budaya yang mempengaruhi perilaku organiassi (Scott 1995, Scott 2001, Scott \& Christensen 1995). Dengan demikian menggunakan perspektif kelembagaan dalam menganalisis implementasi kebijakan dapat menjelaskan bagaimana perubahan sosial yang diinginkan oleh sebuah kebijakan/program dapat terjadi di masyarakat. Satu-satunya cara agar program yang diimplementasikan dapat memberi pengaruh yang signifikan terhadap perubahan sosial adalah dengan mengubah manusia dalam masyarakat. Sedangkan untuk mengubah manusia hanya ada dua cara yaitu mengubah individu-individu dan mengubah lembaga-lembaga (Alexander 2005).

Implementasi program yang membutuhkan kerjasama lintas instansi memiliki karakteristik bottomup (Pulzl \& Treib 2006:89-107, Hill 2005:174-185). Dalam program SLBM selain pemerintah dan sektor privat, masyarakat juga menjadi satu komponen penentu keberhasilan implementasi. Oleh sebab itu, implementasi program SLBM dapat dikatakan memiliki karakter buttom up. Tantangan terbesarnya adalah menemukan pendekatan dan strategi yang tepat agar terwujud sinergi dan kerjasama yang baik antar elemen. Praktik implementasi dengan melibatkan ragam stakeholders memang membutuhkan beberapa prasyarat, seperti jejaring yang kuat, tingkat kepercayaan yang memadai, hingga akuntabilitas dari masing-masing aktor. Dalam istilah Wallis \& Dollery (2002:7685) peran pemerintah adalah sebagai activist. Sementara itu, masyarakat sendiri harus mampu mengelola kelembagaan untuk mendukung hal tersebut.

Dalam program SLBM masyarakat mendapat delegasi kewenangan berupa keleluasaan untuk mengelola kelembagaan dan mengelola output kebijakan sesuai dengan kondisi masyarakat setempat. Sementara, pemerintah bertindak dan berperan sebagai fasilitator. Oleh sebab itu, partisipasi masyarakat menjadi sangat penting sebagai penentu utama keberhasilan program. Keberhasilan implementasi program SLBM pada akhirnya akan sangat ditentukan oleh kinerja kelembagaan yang efektif dalam menciptakan partisipasi masyarakat. Penelitian terdahulu telah menghasilkan proposisi bahwa terdapat hubungan yang signifikan antara kualitas kelembagaan dengan keberhasilan suatu program (Omer 2013).

Berbagai persoalan muncul dalam rangka menciptakan kinerja kelembagaan yang mampu membangun partisipasi masyarakat. Berdasarkan hasil penelitian, tulisan ini mendeskripsikan pola dan kinerja kelembagaan yang telah dipraktekkan dalam implementasi program SLBM di Kabupaten Banyumas. Melalui perspektif kelembagaan, kendala dalam mewujudkan keberhasilan implementasi program SLBM dapat dijelaskan secara lebih komprehensif.

\section{Metode Penelitian}

Artikel ini menjelaskan hasil penelitian yang telah dilakukan melalui pendekatan kualitatif. Metode tersebut tepat digunakan karena penelitian ini bertujuan menganalisis pola dan kinerja kelembagaan dalam implementasi program berbasis masyarakat. Pendekatan kualitatif tepat digunakan untuk mengeksplorasi dan memahami makna yang oleh sejumlah individu atau sekelompok orang dianggap berasal dari masalah sosial dan kemanusiaan (Cresswell 2010). Data dalam penelitian ini dikumpulkan melalui metode wawancara mendalam kepada informan penelitian yang dipilih secara purposif serta observasi lapangan dan analisis dokumentasi. Semua informasi tersebut dikaji secara holistik dan komprehensif melalui metode analisis interaktif (Milles \& Huberman 1992). 


\section{Hasil Penelitian dan Pembahasan}

\section{Kinerja kelembagaan dalam implementasi program SLBM}

Kelembagaan merupakan sebuah istilah yang menggambarkan praktik untuk mengelola interaksi sosial. Dalam arti yang lebih luas kelembagaan bisa merupakan kegiatan, nilai, norma, struktur sosial dan sistem peran yang ada dalam masyarakat (John W. Mohr \& Harrison C. White 2008). Asumsi yang dibangun dari pendapat tersebut adalah bahwa kelembagaan sosial tidak hanya merupakan sub aspek organisasi berupa struktur, tetapi juga mencangkup sistem nilai, norma dan peran. Sub aspek dalam kelembagaan saling terhubung satu dengan lainnya, termasuk para aktor yang terhubung bersama-sama membentuk hubungan dan sistem aturan.

Implementasi program SLBM memberi gambaran tentang sistem kelembagaan yang menghubungkan berbagai aktor yang terlibat. Semangat dalam mewujudkan peran masyarakat sebagai aktor penting menjadikan program ini sarat akan berbagai kepentingan masyarakat. Hal ini kemudian menjadi kendala manakala masyarakat belum memiliki kemampuan untuk membangun konsensus, baik dengan sesama masyarakat, pemerintah dan pihak lain yang terlibat dalam implementasi program.

Di sisi yang lain pemerintah sebagai fasilitator belum secara optimal membangun kesiapan masyarakat sebagai aktor utama implementasi program. Hal tersebut terlihat dari proses perencanaan kegiatan yang dijalankan pemerintah. Implementasi program SLBM diawali dengan sosialisasi yang dilaksanakan oleh pemerintah desa/kelurahan dan Dinas Ciptakarya, Kebersihan dan Tata Ruang Kabupaten Banyumas. Proses sosialisasi tidak berlangsung secara intensif dan hanya dihadiri oleh perwakilan warga dan tokoh masyarakat. Oleh sebab itu, pemahaman masyarakat terhadap program SLBM masih sangat lemah. Pemahaman masyarakat masih sebatas pada program pembangunan fisik yang berkonsekuensi pada penyediaan dana dari pemerintah. Sementara itu makna "berbasis masyarakat" belum dipahami secara optimal, terutama kemanfaatannya. Dijelaskan oleh Alexander (2005) bahwa jika perencanaan adalah upaya menterjemahkan ide-ide menjadi sebuah aksi, maka transformasi kelembagaan harus menjadi aspek yang penting.

Ketimpangan pemahaman antara masyarakat dan pemerintah dalam implementasi program SLBM menjadi kendala utama mewujudkan keberhasilan program. Meskipun program SLBM harus diinisiasi oleh masyarakat, namun peran pemerintah masih sangat dominan. Hal ini digambarkan dalam pembentukan Kelompok Swadaya Masyarakat (KSM) sebagai wujud pola kelembagaan yang bertugas menjembatani kepentingan masyarakat dan pemerintah, namun demikian pembentukan lembaga KSM masih sebatas formalitas persyaratan untuk mendapatkan dana dari program SLBM. Oleh sebab itu, pemerintah belum secara optimal meningkatkan kapasitas KSM dan masyarakat secara umum untuk mewujudkan keberhasilan implementasi program. Padahal hubungan yang diharapkan dari program "berbasis masyarakat" adalah hubungan kemitraan, hubungan kerjasama atau kolaboratif. Dominasi peran pemerintah dalam pelaksanaan program menunjukkan bahwa posisi tawar masyarakat masih rendah. Fenomena tersebut dijelaskan oleh Ansell dan Gash (2007:551) bahwa jika beberapa stakeholders tidak memiliki kapasitas, organisasi, status atau sumberdaya yang setara dengan stakeholders lainnya, maka proses kolaboratif akan rentan terhadap manipulasi oleh aktor yang kuat. Hal inilah yang terjadi dalam implementasi program SLBM.

Peran pemerintah sebagai fasilitator mengharuskan upaya yang berkesinambungan bagi keseluruhan proses implementasi program. Artinya keberadaan pemerintah bagaimanapun tetap harus ada mengingat masih lemahnya kemampuan masyarakat. Peran pemerintah harus bersifat menguatkan kapasitas masyarakat dalam implementasi program. Kelembagaan Kelompok Swadaya Masyarakat (KSM) harus diberi ruang untuk aktif berperan di masyarakat. Kelembagaan KSM harus diwujudkan secara nyata dan berkelanjutan sebagai wadah partisipasi masyarakat yang tidak hanya menjalankan sebuah program, namun dapat dimanfaatkan untuk kepentingan yang lain. Dalam perspektif 
kelembagaan, KSM dapat melakukan perubahan terhadap perilaku masyarakat terutama kesadaran akan pentingnya partisipasi.

Secara umum KSM dibentuk berdasarkan kebutuhan program dan dibagi kedalam dua fungsi, yakni badan pelaksana dan badan pengelola. Badan pelaksana merupakan tim yang dibentuk guna bertanggungjawab selama proses pembangunan program. Sementara itu, badan pengelola adalah pengurus yang diberikan tanggung jawab secara langsung untuk mengelola setelah masa kerja badan pelaksana berakhir, yakni saat septictank komunal telah dioperasikan. Dengan menggunakan struktur kelembagaan pelaksana dan pengelola tersebut, diharapkan implementasi program SLBM memiliki keberlangsungan. Program SLBM adalah program penyediaan prasarana dan sarana sanitasi bagi masyarakat kurang mampu. Oleh sebab itu, fokus utama program ini adalah pada pembangunan fisik yang berupa pembangunan septictank komunal. Meskipun demikian keberlangsungan program SLBM juga menjadi target yang harus dicapai. Tahap inilah yang menuntut kemampuan manajerial yang baik dalam kelembagaan KSM. Dukungan pemerintah juga masih sangat penting dalam meningkatkan kapasitas KSM. Dalam pandangan Oliver (Baker \& Rennie 2012) tekanan-tekanan fungsional yang berkaitan dengan kemampuan yang dimiliki organisasi, kompetensi pelaksana, sistem reward, prosedur dan sebagainya akan dapat merusak tatanan lembaga.

Diperlukan pola kelembagaan dengan desain yang tepat bagi keberlangsungan program. Desain kelembagaan dapat diartikan sebagai upaya merancang atau mendesain lembaga, di mana di dalamnya mencakup upaya merancang dan merealisasikan aturan, prosedur dan struktur organisasi yang memungkinkan dan mampu memaksa perilaku dan tindakan yang sesuai dengan nilai dan tujuan yang hendak dicapai dalam pelaksanaan kegiatan. Dengan demikian dalam perspektif kelembagaan, implementasi program SLBM harus memiliki desain kelembagaan yang mampu menembus segala level masyarakat, termasuk pembuat kebijakan dalam implementasi program (Alexander 2005). Implementasi program SLBM dalam perspektif kelembagaan dijelaskan dengan menganalisis kinerja kelembagaan program sebagai berikut: efektifitas program, struktur kelembagaan dan pengambilan keputusan, mekanisme pertanggungjawaban, kepemimpinan, dan aspek pendukung dan penghambat kinerja kelembagaan KSM.

\section{Efektivitas program}

Implementasi kebijakan pada prinsipnya adalah cara agar sebuah kebijakan dapat mencapai tujuannya (Nugroho 2008:432). Dalam program SLBM salah satu indikator utama keberhasilan adalah partisipasi masyarakat. Berdasarkan beberapa temuan lapangan, menunjukkan bahwa terjadi kecenderungan minimnya tingkat partisipasi masyarakat dalam implementasi program. Hal tersebut disebabkan oleh beberapa faktor, antara lain organisasi yang mewadahi KSM dan pemerintah belum memiliki strategi dan pendekatan yang efektif untuk mendorong perubahan kesadaran masyarakat. Kemudian, tidak efektifnya proses sosialisasi dan kampanye terhadap masyarakat juga menjadi aspek lain yang menyebabkan minimnya partisipasi masyarakat. Sosialisasi dan kampanye yang tidak berjalan efektif, menyebabkan pemahaman akan tujuan dan capaian program tidak sepenuhnya dipahami dan diinternalisasi oleh masyarakat.

Minimnya kajian dan analisa terkait sistem nilai dan kebiasaan dari masyarakat setempat juga menjadi aspek yang tak kalah penting, sebab pemerintah akan mengalami kesulitan memposisikan diri dan program cenderung sulit untuk diterima oleh warga saat minim kajian mendalam. Telah banyak diketahui, bahwa setiap kelompok masyarakat memiliki sistem nilai dan kebiasaan yang partikular dan tidak bisa dilakukan generalisasi dalam pendekatannya. Dalam hal ini, merujuk konsepsi dari Uphoff (1986: 188-196) mengenai local institutional development, menunjukan bahwa pemerintah seharusnya melaksanakan analisa terlebih dahulu terkait kondisi masyarakat, terutama kondisi institusionalnya, untuk mendapat pendekatan yang tepat. Sehingga, saat pemerintah tidak tepat menganalisa, maka pendekatan yang dilakukan juga tidak akan efektif mencapai tujuan. 


\section{Struktur kelembagaan dan pengambilan keputusan}

Teori kelembagaan berkaitan dengan perilaku organisasi dalam menghadapi perubahan dan mengadopsi sebuah kebijakan (Burch 2007). Teori kelembagaan dalam pendekatan sosiologi berkaitan pada bagaimana bentuk dan prosedur yang dimiliki organisasi (Alexander 2005). Melalui struktur kelembagaan yang ada, distribusi tugas dan kewenangan dalam lembaga KSM maupun antara lembaga KSM dengan pemerintah telah berjalan cukup baik. Hal tersebut diindikasikan dari adanya pedoman organisasi (Anggaran Dasar/Anggaran RumahTangga) yang melandasi kerja dari KSM serta pembagian wewenang pelaksana teknis kedalam dua badan, namun, proses pengawasan dan evaluasi kerja yang telah dilakukan belum berjalan secara efektif, sehingga berbagai langkah dan strategi yang diterapkan oleh KSM tidak mampu diawasi oleh masyarakat secara efektif. Tak hanya itu, seluruh KSM juga tidak memiliki indikator kinerja kelembagaan. Hal tersebut menyulitkan untuk memberikan penilaian dan mengukur kemajuan dari implementasi program SLBM.

Aspek komunikasi terutama dalam proses pengambilan keputusan juga menjadi aspek penting. Dalam konteks ini, proses komunikasi dalam pengambilan keputusan dan resolusi konflik di dalam KSM masih memiliki kecenderungan terjadi praktik-praktik dominasi. Berdasarkan focus group discussion, ditemukan bahwa proses komunikasi yang terjadi tidak setara antar kelompok masyarakat, terdapat dominasi dari sekelompok masyarakat. Hal tersebut menyebabkan proses mufakat terjadi bukan karena masing-masing partisipan dalam forum atau pertemuan sukarela menyepakati, tetapi hasil dari pengorganisiran opini dan persetujuan oleh sekelompok masyarakat dengan sumber daya yang berlebih. Meminjam analisa dari Habermas (1984: 284-287), di mana tindakan sosial, termasuk dalam organisasi, mampu diklasifikasikan kedalam beberapa tipe, antara lain tindakan instrumental dan tindakan komunikatif. Praktik yang dilaksanakan oleh KSM masih cenderung sebagai tindakan instrumental yang tidak berorientasi pada pemahaman antar pihak, melainkan "penguasaan" atau dominasi. Sehingga, meski mampu menghasilkan keputusan atau solusi, namun sebagian besar partisipan dalam pertemuan bersepakat bukan karena alasan-alasan pokok yang berkaitan dengan masalah.

Praktik dominasi dalam pengambilan keputusan juga menjadi penghambat dari proses pemahaman kebutuhan dan perubahan sikap dari masyarakat. Dalam konteks ini, Innes \& Booher (2003: 33-59) melihat bahwa proses mufakat atau konsensus yang tercapai dengan tindakan komunikatif harus berada dalam kondisi di mana masing-masing aktor mampu menyadari adanya interdependence of interest, sebuah posisi kesalingtergantungan antar kepentingan yang dimiliki aktor. Tanpa kondisi tersebut, dominasi menjadi berpeluang terjadi. Maka, gejala sebagian besar masyarakat yang gamang dalam melihat kebutuhan mereka sendiri disebabkan minimnya usaha untuk membuka realitas kesalingtergantungan antar kepentingan aktor. Mekanisme tersebut lama kelamaan dapat merusak lembaga, sebagaimana yang dijelaskan oleh Oliver (Baker \& Rennie 2012) bahwa mekanisme politik misalnya konflik status quo, dominasi, tekanan untuk berinovasi dan ketergantungan pada faktor eksternal akan dapat merusak lembaga.

\section{Mekanisme pertanggungjawaban}

Secara umum, lembaga KSM hanya memiliki mekanisme pertanggungjawaban secara vertikal terhadap pemerintah sebagai penyadang dana. Sementara, berdasarkan penelusuran dokumen, tidak terdapat mekanisme baku terkait pertanggungjawaban secara horizontal terhadap masyarakat setempat. Dalam laporan pertanggungjawaban KSM yang diberikan untuk pemerintah, hampir seluruh aspek mampu dijelaskan secara transparan, seperti perencanaan kerja, pengelolaan pendanaan hingga penggunaan dana, namun untuk dana swadaya masyarakat, sebagian besar KSM masih belum mampu mempertanggungjawabkan secara transparan. Kecenderungan lain, hampir seluruh KSM belum menyertakan analisa terkait kondisi masyarakat setempat, terutama berkenaan dengan cara pandang, kebiasaan dan derajat penerimaan masyarakat terhadap perubahan. Padahal, dalam konteks implementasi program SLBM, hal-hal tersebut sangat dibutuhkan, mengingat 
program SLBM dengan output berupa septictank komunal merupakan hal baru. Berdasarkan kondisi tersebut, belum tersusunnya pola dan mekanisme pertanggungjawaban terhadap masyarakat setempat menjadi salah satu aspek signifikan yang menyebabkan tidak mampu terbangunnya pola komunikasi berkarakter komunikatif yang cenderung setara. Kemudian, minimnya antusiasme dan partisipasi masyarakat juga terindikasi dipengaruhi oleh mekanisme pertanggungjawaban yang cenderung vertikal.

Pola pertanggungjawaban dalam implementasi sebuah kebijakan yang melibatkan banyak aktor secara aktif di luar pemerintah seharusnya mampu menyentuh seluruh aktor yang terlibat. Callahan (2007:138-139) menyebut bahwa fokus dari mekanisme akuntabilitas bukan lagi secara administratif atau birokratis, melainkan berfokus pada stakeholders dan norma-norma profesionalitas. Sebab, dengan multistakeholders, implementasi membutuhkan jejaring yang kuat antara pemerintah, masyarakat dan pihak ketiga, atau kerap diistilahkan sebagai administrative networks.

\section{Kepemimpinan}

Hampir seluruh KSM telah mampu menerapkan strategi pengelolaan organisasi yang cukup efisien, yakni dengan memisahkan tanggung jawab berdasarkan kebutuhan program kedalam dua badan (Badan Pelaksana dan Badan Pengelola). Kemudian, pemilihan mekanisme kerjasama operasional dengan pihak ketiga oleh lembaga KSM mengindikasikan bahwa orientasi kepemimpinan cenderung pada efisiensi. Temuan menariknya adalah lembaga KSM yang memilih untuk mengerjakan pembangunan secara mandiri justru kurang optimal dalam kinerjanya. Padahal upaya tersebut menunjukkan orientasi kepemimpinan pada pemberdayaan masyarakat.

Tipe kepemimpinan dalam KSM cenderung mampu didekati dengan socio-cultural approach sebab kepengurusan mengatur kinerja pengurus tanpa menggunakan pendekatan sanksi, sebagaimana dikonsepsikan oleh McGregor (2006:43-75). Tak hanya itu, sebagai organisasi sukarela, kepemimpinan KSM bersandar pada nilai-nilai kolektivitas dan tidak bermotif insentif uang. Sehingga, karakter kepemimpinan dalam KSM lebih kontekstual dengan socio-cultural approach (Tompkins 2005:365-375). Dalam literatur organisasi, kepemimpinan dengan pendekatan sociocultural approach disebut sebagai kepemimpinan dengan tipe $\mathrm{Z}$.

Dalam konteks kelembagaan, sebagaimana diungkap oleh Uphoff (1986:8-10), organisasi menjadi salah satu media untuk melaksanakan institusionalisasi dari nilai, norma, maupun kebiasaan masyarakat. Aspek kepemimpinan dalam kelembagaan memegang peranan yang signifikan, sebab dalam perspektif budaya organisasi, kepemimpinan merupakan aspek utama - meski bukan satusatunya-yang menentukan perubahan perilaku dan kebiasaan individu didalam organisasi (Tompkins 2005:363-387). Meski seluruh struktur organisasi dalam KSM diisi oleh masyarakat setempat, namun berdasarkan temuan di lapangan, tidak menjamin mampu memahami dan memiliki pemahaman utuh terkait nilai, norma dan kebiasaan masyarakat setempat, sehingga secara kelembagaan, KSM belum memberikan dampak secara signifikan, terutama berkaitan dengan perubahan perilaku dan kebiasaan dari masyarakat setempat.

Kesulitan lain juga disebabkan oleh pola kerjasama antar stakeholders dalam implementasi program yang mana tidak melibatkan institusi kesehatan di tingkat desa/kelurahan. Tak hanya itu, organisasi seperti PKK juga tidak dijadikan salah satu stakeholders dalam proses implementasi. Program SLBM cenderung mengedepankan pembangunan secara fisik dan teknis pelaksanaan, namun tidak menekankan penyadaran masyarakat. Meski di dalam kepengurusan terdapat seksi promosi dan kampanye kesehatan, namun tetap sulit dilakukan jika tidak melibatkan institusi yang berwenang dalam isu-isu kesehatan dan lingkungan. 


\section{Aspek pendukung dan penghambat kinerja kelembagaan KSM}

Terdapat beberapa aspek pendukung kelembagaan yang teridentifikasi dari hasil penelitian, antara lain: 1) keswadayaan masyarakat berupa pembentukan KSM. Organisasi KSM ternyata mampu mendorong terjadinya partisipasi masyarakat secara mandiri, meskipun belum secara optimal. Bagaimanapun ujung tombak pelaksanaan program SLBM adalah KSM, 2) kesolidan pimpinan di KSM juga terbukti mampu menjaga konsistensi dari partisipasi masyarakat, 3) struktur organisasi dan distribusi tugas juga telah cukup memadai untuk mendukung kinerja dari KSM, dan 4) corak kolektivitas dalam kepengurusan KSM ternyata cukup mampu menyebabkan KSM berjalan meskipun secara manajerial tidak terlalu baik, misalnya AD/ART organisasi hanya sebagai bentuk aturan formal. Sejalan dengan penelitian Rosyadi \& Sobandi (2014) bahwa negara dalam hal ini pemerintah daerah cenderung memilih pendekatan legalistik daripada sosial. Hal tersebut menyebabkan segala sesuatu yang terbentuk dalam masyarakat termasuk pelibatan masyarakat dalam sebuah program hanya dimaknai legalitas untuk mendapatkan program semata.

Beberapa aspek penghambat kelembagaan yang teridentifikasi dari hasil penelitian, antara lain: 1) perencanaan yang kurang akurat dan matang terkait implementasi SLBM menyebabkan tidak efektifnya program SLBM di tengah masyarakat, 2) pelibatan stakeholders belum menyentuh hingga ke institusi dan tenaga kesehatan, serta minim pelibatan perempuan dan organisasi perempuan, 3) minimnya kajian mendalam terkait tata nilai, norma dan kebiasaan masyarakat setempat sebelum implementasi program SLBM, dan 4) kontrol dan pengawasan terhadap kinerja KSM masih minim, serta belum adanya indikator dan capaian kerja dalam evaluasi setiap kegiatan KSM.

Aspek penghambat lainnya berkaitan dengan kecenderungan praktik dominasi dari beberapa individu atau kelompok masyarakat dominan dalam pengambilan keputusan, yakni pendekatan komunikasi antara KSM dan masyarakat cenderung tidak dialogis, mekanisme pertanggungjawaban cenderung vertikal, belum ada mekanisme baku dan formal terkait pertanggungjawaban secara horizontal kepada masyarakat, pengelolaan dana iuran swadaya masyarakat yang belum transparan, belum terbangunnya administrative network atau jejaring kuat antar stakeholders dalam implementasi, pemilihan pengurus juga tidak disertai pertimbangan keahlian dari individu-individu, kepemimpinan KSM yang cenderung belum mampu menganalisa kondisi sosial masyarakat setempat, tidak efektifnya kampanye dan sosialisasi terkait tujuan kebijakan sebagai akibat dari minimnya keahlian teknis dari pengurus KSM, serta tidak terbangunnya jejaring dengan stakeholders dari institusi kesehatan. Dengan demikian, kualitas kelembagaan yang dibangun oleh KSM memang sangat menentukan keberhasilan program. Hasil penelitian Omer Javed (2013) menemukan bahwa terdapat hubungan yang signifikan antara kualitas kelembagaan dengan keberhasilan suatu program. Oleh sebab itu, kualitas kelembagaan merupakan hal penting yang harus dicapai untuk meningkatkan keberhasilan suatu program.

\section{Simpulan}

Dengan menggunakan perspektif kelembagaan dapat diperoleh penjelasan bahwa kinerja kelembagaan pada program SLBM belum mampu mendukung pencapaian tujuan kebijakan. Indikasinya adalah partisipasi masyarakat dalam program SLBM tercatat masih minim secara kuantitas. Hal ini disebabkan oleh beberapa aspek penghambat kelembagaan, antara lain masih minimnya analisa terkait tata nilai dan kebiasaan masyarakat, hingga belum terbangun administrative network yang sinergis dan luas. Maka dengan ini, pemerintah Kabupaten Banyumas dan KSM seharusnya melakukan analisa terkait tata nilai dan kebiasaan masyarakat setempat, melakukan sosialisasi yang efektif dan berkelanjutan, melibatkan berbagai pihak, terutama institusi kesehatan, meningkatkan efektivitas kontrol melalui indikator yang jelas dan terukur, agar kinerja kelembagaan KSM mampu efektif mendorong pencapaian tujuan kebijakan. 


\section{Daftar Pustaka}

Alexander ER (2005) Institutional transformation and planning: from institutionalization theory to institutional design. Sage Publications Vol 4 (3):209-223.

Baker R \& Rennie MD (2012) An instutional perspective on the development of Canada's first public accounts. Sage Publications 18(1):31-50.

Callahan K (2007) Elements of effective governance: measurement, accountability, and participation. Boca Raton: Taylor \& Francis Group.

Creswell J (2010) Desain Penelitian, Pendekatan Kualitatif dan Kuantitatif terjemahan Angkatan III \& IV, Jakarta: KIK-UI. KIK Press.

Habermas J (1984) The theory of communicative action: reason and the rationalization of society, Vol I. Boston: Beacon Press. 284-287.

Hill MJ (2005) The public policy proccess ( $4^{\text {th }}$ edition). Pearson education Limited, Essex

Innes J \& Booher D (2003) Collaborative policy making: governance through dialogue. Dalam: M. Hajer (ed). Deliberative Policy Analysis: Understanding Governance in the Network Society. New York: Cambridge University Press.

Milles BM \& Huberman MA (1992) Qualitative data analysis. New York: SAGE Publication.

McGregor D (2006) The human side of eanterprise-Annotated edition. New York: McGraw-Hill.

Nugroho R (2008) Public policy. Jakarta: PT Elev Media Komputindo.

Omer J (2013) Determinant of institutional quality: a case study of IMF programme countries. MPRA Paper No 51344. 11 November 2013.

Pulzl H \& Treib O (2006) Implementing public policy. Dalam: Frank F, Miler GJ, Sidney MS. Handbook of Public Policy Analysis: Theory, Politics and Methods. New York: CRC Press. 89-108.

Rosyadi S \& Sobandi KR (2014) Relasi kuasa antara perhutani dan masyarakat dalam pengelolaan sumberdaya hutan di Banyumas: kepentingan bisnis VS community empowerment. Jurnal Komunitas Vol 6 No.1:46-55.

Scott WR (1995) Institutions and Organizations. Thousand Oaks, CA: Sage.

Scott WR (2001) Institutions and Organizations (2nd ed.). Thousand Oaks, CA: Sage.

Scott WR \& Christensen (1995) The Institutional Construction of Organizations: International and Longitudinal Studies. Thousand Oaks, CA: Sage.

Tompkins JR (2005) Organization Theory and Public Management. Belmont: Thomson Wadsworth,.

Uphoff N (1986) Local Institutional Development: An Analytical Sourcebook with Cases. Colorado: Kumarian Press.

Wallis J \& Dollery B (2002) Social capital and local government capacity. Australian Journal of Public Administration 61(3):76-85. 